\title{
Premenstrüel Sendrom Semptomlarının Evlilik Uyumu ile İlişkisi
}

\section{Relations Between Premenstrual Syndrome Symptoms and Marital Adjustment}

\author{
Elif Başağaç ${ }^{1}$ (iD) Emel Ege ${ }^{2}$ (iD \\ ${ }^{1}$ Hacettepe Üniversitesi Tıp Fakültesi Erişkin Hastanesi, Ankara, TÜRKIYE \\ ${ }^{2}$ Necmettin Erbakan Üniversitesi Sağlık Bilimleri Fakültesi Kampüsü Meram/Konya, TÜRKIYE \\ Geliş tarihi/ Date of receipt: 16/12/2020 Kabul tarihi/ Date of acceptance: 08/03/2021 \\ (c) Ordu University Faculty of Health Sciences, Department of Nursing, Turkey, Published online: 18/04/2021
}

\section{Öz}

Amaç: Premenstrüel sendrom kadının, günlük aktivitelerini, iş performansını, aile ve sosyal ilișkileri ile yaşam kalitesini olumsuz etkileyebilir. Bu çalışma, evli kadınlarda premenstrüel sendrom semptomlarının evlilik uyumu ile ilişkisini değerlendirmek amacıyla yapılmıştır.

Yöntem: Tanımlayıcı ve ilişki arayıcı tipte planlanan araştırmanın örneklemini 18-49 yaş grubu evli 138 kadın oluşturmuştur. Verilerin toplanmasında demografik soru formu, Premenstrüel Değerlendirme Formu (PDF), Evlilikte Uyum Ölçeği (EUÖ) kullanılmıştır.

Bulgular: Araştırmada kadınların Evlilik Uyum Ölçeği toplam puan ortalamas1 40.33 \pm 12.88 , Premenstrüel Değerlendirme Formu toplam puan ortalaması 216.18 75.83 olarak tespit edilmiştir. Kadınların Evlilik Uyum Ölçeği puanları ile Premenstrüel Değerlendirme Formu toplam puanları arasında orta düzeyde, negatif yönde ve anlamlı düzeyde bir ilişki olduğu saptanmıştır ( $<<0.05)$. Kadınların Evlilik Uyum puanı üzerine anlamlı düzeyde etkili olan değişkenler PDF çökkün duygu durumu alt boyutu, geliri değerlendirme durumu, PDF organik mental özellikler, eğitim durumu, yaş, sigara kullanımı, olarak sıralanmaktadır. Bu değişken, kadınların evlilik uyum puanına ait değişimi (varyansı) \%30 oranında açıklamaktadır $(\mathrm{p}<0.05)$.

Sonuç: Kadınların Premenstrüel Değerlendirme Formu'ndan aldığı puan arttıkça Evlilik Uyum Ölçeği’ nden aldığı puan azalmaktadır. Kadınların ve eşlerinin evlilik uyumunu koruma ve geliştirmeye yönelik premenstrüel sendrom semptomları hakkında bilgilendirilme ve farkındalık eğitimlerinin çift düzeyinde verilmesi önerilebilir.

Anahtar sözcükler: Evli kadınlar, evlilik uyumu, premenstrüel sendrom

\begin{abstract}
Objective: Premenstrual syndrome may adversely affect daily activities, work performance, family and social relations and the quality of life of women. The aim of this study was to evaluate the relations between premenstrual syndrome symptoms and marital adjustment in married women.

Methods: The sample of this descriptive and relationship-seeking study consisted of 138 married women aged between 18-49 years. The demographic question form, Premenstrual Evaluation Form (PEF) and Marital Adjustment Scale (MAS) were used in the data collection.

Results: In the research, the total avarage score of the Women's Marital Adjustment Scale was $40.33 \pm 12.88$, the total avarage score of the Premenstrual Assessment Form was 216.18 \pm 75.83. Women was found a moderate, negative and significant relationship between Marital Adjustment Scale scores and Premenstrual Assessment Form scores ( $\mathrm{p}<0.05)$. The variables that have a significant effect on the women's marital adjustment score from The PEF sub-dimension of the depressed state, of income is listed as income assessment status, PEF organic mental characteristics, educational status, age and smoking status. This variable explained $30 \%$ of the variance of women's marital adjustment score $(\mathrm{p}<0.05)$.

Conclusion: In conclusion, the higher the score the women get on the Premenstrual Assessment Form, the lower the score they get on the Marriage Adjustment Scale. It may be suggested that women and their spouses be informed about the symptoms of premenstrual syndrome to protect and improve marital adjustment and that awareness training should be provided at double level.
\end{abstract}

Keywords: Married women, marital adjustment, premenstrual syndrome

ORCID IDs of the authors: EB: 0000-0002-6011-9164, EE: 0000-0002-5640-5563

Sorumlu yazar/Corresponding author: Uzman Hemşire Elif Başağaç

Hacettepe Üniversitesi Tıp Fakültesi Erişkin Hastanesi, Ankara, TÜRKİYE

e-posta/e-mail: elfaltngz22@gmail.com

Bu çalışma 19 Aralık 2019-21 Aralık 2019 tarihleri arasında Ankara'da düzenlenen 6. Uluslararası 17. Ulusal Hemşirelik Kongresi'nde sözel bildiri olarak sunulmuștur.

Atıf/Citation: Başağaç E, Ege E. (2021). Premenstrüel sendrom semptomlarının evlilik uyumu ile ilişsisi. Ordu Üniversitesi Hemşirelik Çalışmaları Dergisi, 4(1), 1-9. DOI: 10.38108/ouhcd.839898 


\section{Giriş}

Menstrüel siklus puberteden başlayan menopoza kadar devam eden üreme ve gebelik için gerekli döngüsel hazırlık olarak tanımlanmaktadır. (Saka ve Okuyucu, 2020.) Fertil çağındaki kadınların \%7090' nında menstrüasyon ve menstrüel dönem ile ilgili bazı problemler yaşamaktadırlar. $\mathrm{Bu}$ problemler arasinda en fazla dismenore, premenstrüel sorunlar, anormal uterin kanama yer olmaktadır (Taşçı, 2006). En sik karşılaşılan sorunlardan biri olan premensrual sendrom kadınların \%20-40' lık kısmında değişik derecede geçici mental ve fiziksel işlev bozukluğu şeklinde belirtiler ile seyreden ve \%5-10' luk kisminda çalışma ve sosyal yaşamlarını bozacak ve tedavi gerektirecek şiddetli belirtiler gösteren bir durumdur (Kebapçılar ve ark., 2012).

Premenstrüel sendrom (PMS), menstrüel döngünün luteal fazıyla ilişkili olan, düzenli ve döngüsel şekilde, kadının hayatını fiziksel, duygu durum ve davranışsal açıdan etkileyen değişiklikler olarak tanımlanmaktadır (Tok ve Avc1, 2016). Toplumda oldukça yaygın olarak görülen PMS' nin, yakın aile ilişkilerini, sosyal hayatı, çalışma performansını ve iş ilişkilerini etkilediği belirtilmektedir (Daşıkan ve Saruhan, 2014). En sık görülen belirtiler; kas, karın ve baş ağrısı, memelerde hassasiyet, kilo alımı, bazı yiyeceklere karşı yoğun istek duyma, iştah değişimi, akne, ödem, yorgunluk, mizaç dalgalanmaları, duygusallık, sinirlilik olarak belirtilmektedir (Tanrıverdi ve ark., 2010; Özkan ve Koç, 2020; Yücel ve ark., 2009). Morowatisharifabad ve arkadaşlarının (2014) çalışmasında kadınlarda PMS' ye bağlı duygusal değişikliklerinin sosyal ve aile ilişkilerini etkilediği tespit edilmiştir Ayrıca PMS'li kadınların ailelerinde çocuk örselenmesi ve aile içi kavgaların daha sı yaşandığ 1 belirtilmektedir (Eğicioğlu ve ark., 2015). Halbuki evlilikte yaşanılan uyum ve beklentilerin gerçekleştirilmesi bireylerin mutluluğu açısından önemlidir (Sakarya ve Dilmaç, 2020).

Evlilik uyumu, çatışmaların çözümlenebildiği eşler arası doyumun hissedilebildiği, ortak aktivite ve faaliyetlerin birlikte yapılabildiği ve karşılıklı beklentilerin karşılanabildiği bir evlilik olarak tanımlanmıştır (Erbil ve Hazer, 2018). Evlilik uyumu, ilişkideki ihtiyaçların karşılanma derecesine bağlı olarak oluşan bir algı olarak kabul edilmektedir. (Türkseven ve ark., 2020 ). Evlilik uyumu üzerinde etkili olabilecek cinsiyet, yaş, sağlık durumu gibi kişisel değişkenler, eşler arası yaş farkı, evlilik biçimi, eşlerin cinsel yaşamdaki doyumu gibi aileye ilişkin değişkenler, ailenin aylık geliri, gelirin yeterlilik düzeyi, eşlerin öğrenim düzeyi gibi özellikler ise sosyoekonomik değişkenler olarak sınıflandırılmaktadır (Erbil ve Hazer, 2018). Olumlu evlilik ilişkisi, ailede alınan kararlarda söz sahibi olmak ve eşten alınan sosyal desteğin evlilik ve eşler arası uyumu arttırdığ düşünülmektedir. Özellikle eşten alınan sosyal desteğin, akraba, arkadaş gibi diğer kaynaklardan alınan desteklerden daha etkili olduğu belirtilmektedir (Çoban ve ark., 2008). Eşlerin PMS' nin kadın bedeni ve ruhu üzerindeki etkilerinin farkında olunmasının eş ilişkilerini olumlu etkileyeceği, cinsel sorunları azaltacağı ve evlilik doyumunu arttıracağı düşünülmektedir. Evlilik doyumunun yetersizliğinin bilgi eksikliğinden kaynaklanabileceğini düşünen Morowatisharifabad ve arkadaşları (2014) eşlerin eğitilmesi konusunda çalışma yapmış ve çalışma sonucunda eğitim öncesi evlilik doyumu düşük olan erkeklerin farkındalık artışıyla evlilik doyumlarının arttığını saptanmıştır (Morowatisharifabad ve ark., 2014)

PMS kadını etkileyen, eş, aile ve toplum düzeni içinde de sorun haline gelebilmektedir. Sağlık profesyonellerinin üreme sağlığı ile ilgili işlemler sırasında sorunun farkında olması bu açıdan önemlidir (Kaya ve Gölbaşı, 2016). Ülkemizde ve dünyada yapılmış olan, evli kadınların dahil edildiği, PMS'nin yaygınlığını araştıran çalışmalar mevcuttur (Erbil ve ark., 2011; Kebapçılar ve ark., 2012; Morowatisharifabad ve ark., 2014; Pinar ve Öncel, 2011). Ancak doğrudan evlilik uyumu ve PMS arasındaki ilişkiyi inceleyen çalışmaya rastlanılmamıştır. Bu çalışma, evli kadınlarda PMS semptomlarının evlilik uyumu ile ilişkisini değerlendirmek amacıyla yapılmıştır.

\section{Yöntem}

Araştırma, tanımlayıcı ve ilişki arayıcı tipte yapılmış olup Ankara ili, Keçiören ilçesinde bağlı bir Aile Sağlığı Merkezi'nde 01.11.201815.01.2019 tarihleri arasında yürütülmüştür.

Araştırmanın evrenini, çalışmanın yürütüldüğü tarihler arasında Aile Sağlığı Merkezi'ne muayeneye gelen 18- 49 yaş gurubu evli kadınlar oluşturmuştur.

Araştırmanın örnek sayısının belirlenmesinde "Bir Toplumdaki Oranın Belirli Bir Doğrulukla Tahmininde" önerilen bir tablodan yararlanılmıştır (Lemeshow ve ark., 2000). Ülkemizde yapılan çalışmalarda evli kadınlarda PMS semptomlarının evlilik uyumu ile ilişkisini değerlendirmek amacıyla 
yapılmış bir çalışmaya rastlanmamıştır. 15-49 yaş gurubundaki kadınlarda PMS görülme sıklığını belirlemek amaçlı yapılmış çalışmanın bildirdiği, PMS belirtisini şiddetli şekilde yaşayan kadınların oranından (\%11.8) yararlanılmıştır (Pınar ve Öncel, 2011). Araştırmanın örneğinin belirlenmesinde $\% 95$ güven düzeyinde ve $\% 5$ rölatif kesinlik dikkate alınmış ve tabloda bildirilen örnek büyüklüğü 138 olarak bulunmuştur (Lemeshow ve ark., 2000). Kadınların evlilik uyum puanı üzerine altı bağımsız değişkenin etkisini gösteren regresyon analizinde elde edilen R2: .30 değerine göre $G^{*}$ Power (3.1.9.2) programı ile yapılan post hoc güç analizinde etki büyüklüğü f2: 0.43 (büyük/geniş etki) ve post hoc güç 1.00. (\%100) olarak bulunmuş ve çalışmadaki örneklem sayısının yeterli olduğu görülmüştür.

Araştırmaya 18-49 yaş grubunda evli, en az ilkokul mezunu olan, eşiyle birlikte yaşayan, düzenli adet gören (21-35 gün aralığında) kadınlar dahil edilmiştir. Gebe, lohusa veya laktasyon döneminde olan, iletişime engel bir durumu olan (konuşma, duyma ve görme engeli), cerrahi ya da doğal yollarla menopoza girmiş olan, psikiyatrik veya kronik hastalığa sahip olan (öz bildirim veya alınmış tanı), hormonal kontraseptif yöntem kullanan kadınlar araştırmaya dahil edilmemiştir.

Verilerin toplanmasında araştırmacı tarafindan literatürden yararlanılarak hazırlanan kadınların, sosyodemografik özelliklerini, obstetrik ve menstrüasyon özelliklerini ve sağlık alışkanlıklarını sorgulayan 20 soruluk anket formu (Adigüzel ve ark., 2007; Kaya ve Gölbaş1, 2016; Kebapçılar ve ark., 2012; Kıvrak ve Taşğın, 2010; Özeren ve ark., 2013), Dereboy ve arkadaşlarının 1994 yılında geçerlilik güvenilirlik çalışmasını yaptığı Premenstrüel Değerlendirme Formu (PDF), TutarelKışlak' in 1999 yılından geçerlilik güvenilirlik çalışmasını yapmış olduğu Evlilikte Uyum Ölçeği (EUÖ) kullanılmıştır (Dereboy ve ark., 1994; Tutarel-Kışlak, 1999).

Premenstrüel Değerlendirme Formu (PDF): Halbreich ve arkadaşları (1982) tarafindan geliştirilen ve ülkemizde Dereboy ve arkadaşları (1994) tarafindan Türkçeye uyarlanıp geçerlilik, güvenilirlik çalışması yapılan Premenstrüel Değerlendirme Formu, premenstrüel dönemde kadınların kendilerinde gözlemledikleri değişimleri ölçmeye yarayan 95 sorudan oluşan öz bildirim ölçeğidir. Sorular altılı likert skalası ile yanıtlanmaktadır 1.seçenek "değişim yok", 2.seçenek "çok az değişim", 3.seçenek "hafif değişim", 4. seçenek "orta şiddete değişim", 5.seçenek "şiddetli değişim", 6.seçenek "aşırı değişim" ifadelerine karşılık gelip puan almaktadır. Ölçekten alınan puanlar yükseldikçe premenstrüel sendromun şiddetinin yükseldiğ $\mathrm{i}$ şeklinde değerlendirilmektedir. PDF' den alınan maksimum puan 570' tir PDF' in 18 alt ölçeği bulunmaktadır (Tablo 1). Ölçeğin PDF toplamı için Cronbach alfa değeri 0.97 olarak bulunmuştur. Bu çalıșmada PDF toplamı için Cronbach alfa değeri 0.98, alt boyutlarının alfa değerleri ise 0.58 ile 0.90 arasında bulunmuştur.

Evlilikte Uyum Ölçeği (EUÖ): Locke ve Wallace 1959 yılında Evlilikte Uyum Ölçeğini, evliliğin niteliğini ölçmek amacıyla geliştirmiştir. Tutarel-Kışlak tarafindan 1999 yılında Türkçeye uyarlanmış ve geçerlilik ve güvenilirlik çalışması yapılmıştır.. Ölçek hem genel evlilik doyumunun ya da niteliğinin ölçülmesinde hem de çeşitli ve aileyi ilgilendiren konularda anlaşma ya da anlaşmama konusundaki ilişsi tarzını ölçmektedir (TutarelKışlak, 1999). EUÖ' de puanlama uyumsuzluktan uyumluluğa doğru artan 15 sorudan oluşmaktadır. En düşük uyum puanı 0, en yüksek uyum puanı 158 olarak belirlenmiştir. Ölçeğin iç tutarlılık katsayısı 0.90 olarak bulunmuş, bu çalışmada Evlilik Uyum Ölçeğinin cronbach alfa güvenirlik katsayısı 0.92 olarak bulunmuştur. Uyumlu ve uyumsuz evli kişilerin ayırt edilmesini sağlayan kesme noktasının değeri ise 43 ve altı puanların altı uyumsuz, 44 ve üstü puanlar uyumlu olarak belirlenmiştir.

\section{Verilerin Toplanması}

Veriler araştırmacı tarafindan Aile Sağlığı Merkezi'nde yüz yüze görüşme yöntemi ile toplanmıştır. Verilerin toplanma süresi $20-30 \mathrm{dk}$. sürmüştür. Veriler olasılıksız örnekleme yöntemlerinden gelişigüzel örnekleme yöntemi ile toplanmıştır. Araştırma öncesi Aile Sağlığ Merkezi'ne başvuran 10 kadına veri toplama formları araştırmacı tarafından yüz yüze görüşülerek uygulanmıştır. Sonuçlarına göre veri toplama formlarında gerekli düzenlemeler yapılmıştır. Ön uygulama esnasında toplanan veriler araştırmanın örneğine dahil edilmemiştir.

\section{Etik Boyutu}

Araştırma öncesi Üniversitenin Tıp Fakültesi İlaç ve Tıbbi Cihaz Dışı Araştırmalar Etik Kurul Başkanlığı'ndan 2018/1515 karar sayılı etik kurul onayı alınmıştır. İl Sağlık Müdürlüğü 'nden araştırmanın yürütülebilmesi için izin alınmıştır. Anket formları doldurulmadan önce kadınlara araştırmanın amacı hakkında bilgi verilip sözel olarak onamları alınmıştır. Araştırma ve Yayın etiğine uyulmuştur. 


\section{Verilerin Analizi}

Verilerin değerlendirilmesinde, tanımlayıcı istatistiklerde kategorik veriler için sayı, oran, sayısal veriler için ortalama ve standart sapma verilmiştir. Sayısal değişkenlerin normal dağılıma sahip olma durumu Skewness ve Kurtosis ile değerlendirilmiştir. PDF çeşitli duygu durum/davranış değişiklikleri alt boyutunun normal dağılıma sahip olmadığı (Skewness: 1.72, Kurtosis: 4.40), diğer değişkenlerin normal dağılıma sahip olduğu (Skewness:-1.30 ile 1.51 aras1, Kurtosis: 0.73 ile 2.00 arası olarak değerlerin -2 ile +2 arasında yer aldığı) belirlendi (George ve Mallery, 2010). Verilerin analizinde bağımsız gruplarda $t$ testi ve Mann Whitney U testi, varyans analizi (ileri analizi Tukey HSD) ve Kruskal Wallis testi (ileri analizi Bonferroni düzeltmeli Mann Whitney U testi) kullanılmıştır. Sayısal değişkenlerin (PDF ölçeği ve alt boyut puanlarının) normal dağılım özelliğine göre Evlilik Uyum Ölçeğinin puanları ile ilişkisi Pearson korelasyon analizi ve Spearman korelasyon analizi ile değerlendirilmiştir. Evlilik uyum puanı üzerine primer analizlerde etkisi bulunan bağımsız değişkenler çoklu regresyon (bacward yöntemi) analizi ile değerlendirilmiştir. Önemlilik düzeyi $\mathrm{p}<0.05$ olarak kabul edilmiştir.

\section{Bulgular}

Premenstrüel sendrom semptomlarının evlilik uyumuyla ilişkinin incelendiği çalışmada, araştırma grubuna ait tanıtıcı bilgiler Tablo 1'de sunulmuştur. Çalışmaya kapsamına alınan kadınların \%69.6'sının 36 yaş ve üstü olduğu, \%42.8'inin lise mezunu olduğu tespit edilmiştir. Kadınların \%53.6'sının herhangi bir işte çalışmadığı saptanmıştır. Eşlerinin \%36.2'sinin lise mezunu olduğu, \%91.3'ünün herhangi bir işte çalıştığı tespit edilmiştir. Kadınların \%68.1'inin gelir durumlarını orta olarak değerlendirdiği görülmüştür. Aile şekli olarak \%84'ünün çekirdek ailede yaşadıkları tespit edilmiştir (Tablo 1).

Araştırmada kadınların EUÖ' den aldığ 1 toplam puan oratalamas $140.33 \pm 12.88$ ve PDF' den alınan toplam puan ortalamas1 216.18 \pm 75.83 olarak saptanmıştır (Tablo 2). Evlilik Uyum Ölçeği puanları ile Premenstrüel Değerlendirme Formu toplam puanları arasında orta düzeyde, negatif yönde ve anlamlı düzeyde bir ilişki olduğu saptanmıştır. Evlilik Uyum Ölçeği puanlanı ile Premenstrüel Değerlendirme Formunun çökkün duygu durumu, endojen depresif özellikler, düşmanlık/kızgınlık, sosyal geri çekilme, sosyal işlevsellikte bozulma, bunaltı, impulsivite, fiziksel rahatsızlık, otonomik değişimler, çeşitli duygudurum/davranış değişiklikleri alt boyut puanları arasında orta düzeyde ve negatif yönde, atipik depresif özellikler, çeşitli fiziksel değişimler, labilite, histeroid özellikler, organik mental özellikler, su tutulumu alt boyut puanları arasında negatif yönde zayıf düzeyde olmak üzere anlamlı bir ilişki olduğu tespit edilmiştir $(p<0.05)$. Kadınların Premenstrüel Değerlendirme Formu'ndan aldığ toplam ve alt boyut puanları arttıç̧a evlilik uyum puanları düşmektedir (Tablo 3).

Tablo 1. Katılımcıların tanımlayıcı özellikleri (n: 138)

\begin{tabular}{|c|c|c|}
\hline Özellikler & $\mathrm{n}$ & $\%$ \\
\hline \multicolumn{3}{|l|}{ Yaş grubu } \\
\hline$\leq 35$ yaş & 42 & 30.4 \\
\hline$\geq 36$ yaş & 96 & 69.6 \\
\hline \multicolumn{3}{|l|}{$\begin{array}{l}\text { Eğitim } \\
\text { durumu }\end{array}$} \\
\hline Lise & 59 & 42.8 \\
\hline Üniversite & 44 & 31.9 \\
\hline \multicolumn{3}{|l|}{$\begin{array}{l}\text { Çalışma } \\
\text { durumu }\end{array}$} \\
\hline Hayır & 74 & 53.6 \\
\hline \multicolumn{3}{|l|}{$\begin{array}{l}\text { Eş eğitim } \\
\text { durumu }\end{array}$} \\
\hline Lise & 50 & 36.2 \\
\hline Üniversite & 49 & 35.5 \\
\hline \multicolumn{3}{|l|}{$\begin{array}{l}\text { Eş çalışma } \\
\text { durumu }\end{array}$} \\
\hline Çalışıyor & 126 & 91.3 \\
\hline \multicolumn{3}{|l|}{$\begin{array}{l}\text { Gelir durumu } \\
\text { algIS! }\end{array}$} \\
\hline Orta & 94 & 68.2 \\
\hline Kötü & 22 & 15.9 \\
\hline \multicolumn{3}{|l|}{ Aile tipi } \\
\hline Çekirdek & 117 & 84.8 \\
\hline Geniş & 21 & 15.2 \\
\hline
\end{tabular}


Evlilik Uyum Ölçeği puanları ile Premenstrüel Değerlendirme Formunun kendini iyi hissetmede artış ve yorgunluk alt boyut puanları arasında negatif ve zayıf düzeyde bulunan ilişkinin anlamlı düzeyde olmadığı belirlenmiştir ( $p>0.05$, Tablo3). Kadınların Evlilik Uyum Ölçeği puanları üzerine primer analizlerde etkisi olduğu belirlenen bağımsız değişkenlerin (sosyodemografik, obstetrik ve menstruel özellikler, sağlık alışkanlıkları, 7 değişken, Premenstrüel Değerlendirrme Formu' nun toplam ve 16 alt boyutu) etkisi bir arada değerlendirilmek üzere çoklu regresyon analizi yapılmıştır. Bağımsız değişkenler arasında Collinearity istatistiklerine göre otokorelasyon varlığ incelendiğinde, Premenstrüel Değerlendirme Formu' nun toplam puanı ile modele alınacak 15 alt boyut puanı arasında (modele alınacak 16 alt boyut var, Fiziksel rahatsızlık alt boyutunda r: 68) yüksek düzeyde ilişki olduğu (r: .75 ile 0.92 arasında, $\mathrm{p}<0.001$, PDF Toplam puan tolerans değeri: 0.003, VIF: 358.012), belirlenmiş, otokorelasyon sorunu nedeniyle toplam puan modelden çıkarılmıştır. Evlilik uyum puanı üzerine anlamlı düzeyde etkili bulunan altı değişkenin etki düzeylerine ilişkin sonuçlar Tablo 4'de verilmiştir.

Kadınların evlilik uyum puanı üzerine anlamlı düzeyde etkili olan değişkenler $\square$ katsayısına göre en çok önemliden en az önemliye doğru; PDF çökkün duygu durumu alt boyutu $(\mathrm{p}<.001)$, geliri değerlendirme durumu $(\mathrm{p}<0.01)$, PDF organik mental özellikler $(\mathrm{p}<0.05)$, eğitim durumu, yaş $(p<0.01)$, sigara kullanımı $(p<0.05)$ olarak sıralanmaktadır. $\mathrm{Bu}$ değişken, kadınların evlilik uyum puanına ait değişimi (varyansı) \%30 oranında açıklamaktadır.

Tablo 2. Katılımcıların EUÖ ve PDF' den aldığı puanlar

\begin{tabular}{lcc}
\hline Ölçek ve Alt Boyutları & En az-en çok & $\overline{\mathbf{x}} \pm \mathbf{S S}$ \\
Evlilik Uyum Ölçeği Toplam Puan & $1-58$ & $40.33 \pm 12.88$ \\
Premenstrüel Değerlendirme Formu - Toplam Puan & $109-480$ & $216.18 \pm 75.83$ \\
1.Çökkün duygu durumu & $10-57$ & $21.77 \pm 10.61$ \\
2. Endojen depresif özellikler & $5-25$ & $10.95 \pm 4.83$ \\
3. Labilite & $3-18$ & $7.66 \pm 3.30$ \\
4. Atipik depresif özellikler & $7-34$ & $17.29 \pm 5.70$ \\
5. Histeroid özellikler & $5-29$ & $10.37 \pm 4.55$ \\
6. Düşmanlık/kızınlık & $6-35$ & $12.24 \pm 6.66$ \\
7. Sosyal geri çekilme & $4-24$ & $8.78 \pm 4.50$ \\
8. Bunaltı & $4-24$ & $10.24 \pm 4.49$ \\
9. Kendini iyi hissetmede artış & $4-21$ & $8.46 \pm 3.59$ \\
10. İmpulsivite & $4-24$ & $8.08 \pm 4.33$ \\
11. Organik mental özellikler & $6-34$ & $13.19 \pm 5.87$ \\
12. Su tutulumu & $6-36$ & $15.80 \pm 6.56$ \\
13. Fiziksel rahatsılık & $3-18$ & $8.49 \pm 3.69$ \\
14. Otonomik değişimler & $7-39$ & $15.26 \pm 6.36$ \\
15. Yorgunluk & $4-24$ & $11.88 \pm 4.77$ \\
16. Sosyal işlevsellikte bozulma & $11-57$ & $24.41 \pm 10.31$ \\
17. Çeşitli duygu durum/davranış değişiklikleri & $14-78$ & $27.87 \pm 11.57$ \\
18. Çeşitli fiziksel değişimler & $6-32$ & $13.04 \pm 5.37$ \\
\hline
\end{tabular}


Tablo 3. Kadınların Evlilik Uyum Ölçeği puanları ile Premenstrüel Değerlendirme Formu puanları arasındaki ilişki

\begin{tabular}{lcc} 
Ölçek ve Alt Boyutları & \multicolumn{2}{c}{$\begin{array}{c}\text { Evlilik Uyum Ölçeği } \\
\text { Toplam Puan }\end{array}$} \\
\cline { 2 - 3 } Premenstrüel Değerlendirme Formu Toplam Puan & r & p \\
\hline 1.Çökkün duygu durumu & -0.33 & $<\mathbf{0 0 1}$ \\
2. Endojen depresif özellikler & -0.36 & $<\mathbf{0 . 0 0 1}$ \\
3. Labilite & -0.34 & $<\mathbf{0 . 0 0 1}$ \\
4. Atipik depresif özellikler & -0.19 & $\mathbf{0 . 0 2 6}$ \\
5. Histeroid özellikler & -0.22 & $\mathbf{0 . 0 0 9}$ \\
6. Düşmanlık/kızgınlık & -0.20 & $\mathbf{0 . 0 2 2}$ \\
7. Sosyal geri çekilme & -0.33 & $<\mathbf{0 . 0 0 1}$ \\
8. Bunaltı & & \\
9. Kendini iyi hissetmede artış & -0.37 & $<\mathbf{0 . 0 0 1}$ \\
10. İmpulsivite & -0.29 & $\mathbf{0 . 0 0 1}$ \\
11. Organik mental özellikler & -0.10 & 0.236 \\
12. Su tutulumu & -0.28 & $\mathbf{0 . 0 0 1}$ \\
13. Fiziksel rahatsızlık & -0.19 & $\mathbf{0 . 0 2 9}$ \\
14. Otonomik değişimler & -0.20 & $\mathbf{0 . 0 1 6}$ \\
15. Yorgunluk & -0.25 & $\mathbf{0 . 0 0 4}$
\end{tabular}

r: Pearson korelasyon analizi / *rs: Sperman korelasyon analizi (17. boyut verileri normal dă̆llıma sahip değildir)

Tablo 4. Kadınların Evlilik Uyum Ölçeği puanı üzerine bağımsız değişkenlerin etkisi (n: 138)

\begin{tabular}{|c|c|c|c|c|c|c|c|c|c|}
\hline \multirow{3}{*}{$\begin{array}{l}\text { Bağımsız Değişkenler } \\
\text { (Sabit) }\end{array}$} & \multirow{3}{*}{$\frac{\text { B }}{25.92}$} & \multirow{3}{*}{$\begin{array}{c}\text { S.Hata } \\
8.40\end{array}$} & \multirow{3}{*}{$\beta$} & \multirow{3}{*}{$\frac{\mathbf{t}}{3.087}$} & \multirow{3}{*}{$\frac{\mathbf{p}}{0.002}$} & \multirow{2}{*}{\multicolumn{2}{|c|}{$\begin{array}{c}\text { B için 95\% } \\
\text { Güven Aralığı }\end{array}$}} & \multicolumn{2}{|c|}{$\begin{array}{l}\text { Collinearity } \\
\text { Ístatistikleri }\end{array}$} \\
\hline & & & & & & & & Tolerans & VIF \\
\hline & & & & & & 9.31 & 42.54 & & \\
\hline $\begin{array}{l}\text { F1.Çökkün duygu } \\
\text { durumu* }\end{array}$ & -.54 & 0.13 & -.44 & 4.199 & $<0.001$ & -0.79 & -0.28 & 0.461 & 2.168 \\
\hline $\begin{array}{l}\text { Geliri değerlendirme } \\
\text { (1:kötü, 2:orta, 3iyi) }\end{array}$ & 5.93 & 1.70 & .26 & 3.499 & 0.001 & 2.58 & 9.29 & 0.913 & 1.095 \\
\hline $\begin{array}{l}\text { F11. Organik mental } \\
\text { özellikler* }\end{array}$ & .48 & 0.23 & .22 & 2.113 & 0.037 & 0.03 & 0.93 & 0.469 & 2.133 \\
\hline $\begin{array}{l}\text { Ĕgitim } \\
\text { (1:ilköğr. 2: lise- } \\
\text { üniversite) }\end{array}$ & 5.92 & 2.12 & .20 & 2.790 & 0.006 & 1.72 & 10.12 & 0.982 & 1.018 \\
\hline $\begin{array}{l}\text { Yaş } \\
(1:<.35,2: \geq 35 \text { yaş })\end{array}$ & -5.54 & 2.05 & -.20 & 2.699 & 0.008 & -9.60 & -1.48 & 0.939 & 1.065 \\
\hline $\begin{array}{l}\text { Sigara kullanımı } \\
\text { (1: evet, } 2 \text { : hayır) }\end{array}$ & 4.10 & 1.98 & .15 & 2.071 & 0.040 & 0.18 & 8.02 & 0.971 & 1.030 \\
\hline $\begin{array}{l}\text { F14. Otonomik } \\
\text { değișimler* }\end{array}$ & .44 & 0.24 & .22 & 1.875 & 0.063 & -0.02 & 0.91 & 0.364 & 2.746 \\
\hline $\begin{array}{l}\text { Eş çalışma durumu } \\
\text { (1: hayır, 2: evet) }\end{array}$ & 6.06 & 3.29 & .13 & 1.840 & 0.068 & -0.46 & 12.57 & 0.929 & 1.077 \\
\hline
\end{tabular}

R: .58 Adjusted $\mathrm{R}^{2}: .30 \quad$ F: 10.93 p: .000 Durbin Watson: 2.00 


\section{Tartışma}

Evlilik birlikteliğinde uyum, eşlerin psikolojik sağlığını etkilediğinden insanların hayatında önemli bir yere sahiptir Bireylerin evliliklerinde yaşadıkları uyumsuzluklar ve çatışmalar ve sorunlar sonucunda siklikla psikolojik anlamda sorun oluşturabilmektedir (Tutarel-Kışlak ve Göztepe, 2012). Premenstrüel sendrom, üreme çağındaki kadınların aile, iş ve günlük yaşamlarını etkileyen önemli bir sorundur (Heydari ve ark., 2018). Yaşanılan bu sorunlar kadınların evlilik hayatlarını olumsuz etkileyerek evlilik uyumunu bozabilir. $\mathrm{Bu}$ çalışma premenstrüel sendrom semptomlarının evlilik uyumuna etkisini değerlendirmek amaciyla yapılmıştır.

Araştırmada kadınların EUÖ' den aldığı toplam puan ortalamas $140.33 \pm 12.88$ iken, PDF' den alınan toplam puan ortalamas1 216.18 \pm 75.83 tir. Kadınların PDF' nin alt boyutlarından en fazla puanı çeşitli duygu durum/davranış değişikliklerinden $27.87 \pm 11.57$, en düşük puanı labiliteden $7.66 \pm 3.30$ almıştır. Ülkemizde yapılmış evli kadınların yüzdesinin fazla olduğu (\%93) ve PDF kullanılarak ölçme yapılmış bir çalışmada toplam PDF puanı ortalama 206.0 \pm 76.1 olarak bulunmuştur. PDF alt ölçeklerinden alınan skorların ortalaması incelendiğinde en düşük puan ortalaması labiliteden (6.2 \pm 2.8$)$, en yüksek puan ortalaması çeşitli duygu durum/davranıştan (26.4 \pm 11.3$)$ aldığ görülmektedir (Öztürk Can ve ark., 2015). İki çalışmanın bulgularının birbirine çok yakın olduğu görülmektedir. Ülkemizde yapılmış çeşitli çalışmalardaki ölçek puan ortalamaları Erbil ve arkadaşları (2011), Tanrıverdi ve arkadaşları (2010), Erbil ve arkadaşları (2010) çalışmasında sırasıyla $88.61 \pm 30.05,121.94 \pm 31.27,112.27 . \pm 31.24$ olarak bulunmuştur (Erbil ve ark.,2011; Erbil ve ark.,2010; Tanriverdi ve ark., 2010). PMS' nin kadınlarda duygu durum ve davranış değişikliklerine neden olduğu görülmektedir. Bu değişimin eşler arasında evliliklerinin uyumunu olumsuz etkileyebilecek bir faktör olduğu sonucuna varılmıştır.

Kadınların Evlilik Uyum Ölçeği puanları ile PDF puanları arasındaki ilişki incelendiğinde; EUÖ puanları ile PDF'nin "psikolojik belirtiler " alt boyutlarından; "çökkün duygu durumu ", "endojen depresif özellikler ", düşmanlık/kızgınlık, sosyal geri çekilme, sosyal işlevsellikte bozulma, bunaltı, impulsivite, fiziksel rahatsızlı, otonomik değişimler, çeşitli duygudurum/davranış değişiklikleri alt boyut puanları arasında orta düzeyde ve negatif yönde ilişki olduğu görülmektedir. EUÖ puanları ile PDF' nin fiziksel belirtiler alt boyutlarından; atipik depresif özellikler, çeşitli fiziksel değişimler, labilite, histeroid özellikler, organik mental özellikler, su tutulumu alt boyut puanları arasında negatif zayıf düzeyde olmak üzere bir ilişki olduğu görülmektedir. Ancak PDF' nin kendini iyi hissetmede artış ve yorgunluk alt boyut puanları ile EUÖ arasında anlamlı bir ilişki görülmemiştir. Psikolojik ve fiziksel belirtiler arasındaki farkın nedeni olarak çalışma grubunun büyük çoğunluğunun herhangi bir işte çalışmadığı ve günlük ev, aile, eş, çocuk sorumluluklarına ek işin verdiği sorumluluklarının olmaması, boş zamanlarının daha çok olması ve verimli değerlendirilememesi kadınların kendi içlerine dönük düşünceler yaşamasından kaynakladığ 1 düşünülmüştür. EUÖ puanları ile PDF toplam puanları arasında orta düzeyde, negatif yönde ve anlamlı düzeyde bir ilişki olduğu saptanmıştır. Premenstrüel sendrom semptomları azaldıkça evlilik uyumu artmaktadır. Stres, anksiyete, depresyon belirtileri, kültürel inançlar, semptomlarla baş etme metodları gibi psikososyal faktörler; çeşitli bilişsel, davranışsal ve psikolojik semptomlarla bağlantılı olarak, kadının günlük aktiviteleri ve sosyal ilişkilerini etkileyerek işlev kaybına neden olmaktadır (Açıkgöz ve ark., 2017; Hussein Shehadeh ve Hamdan-Mansour, 2017; Nicolau ve ark., 2018). Kadının psikososyal faktörlerden etkilenmesi, evlilik uyumunun da etkileneceğini düşündürmüştür.

Kadınların evlilik uyum puanı üzerine anlamlı düzeyde etkili olan değişkenler en çok önemliden en az önemliye doğru; PDF çökkün duygu durumu alt boyutu, geliri değerlendirme durumu, PDF organik mental özellikler, eğitim durumu, yaş, sigara kullanımı olarak sıralanmaktadır. Çalışma sonucunda PDF alt boyutlarından çökkün duygu durumunu ve organik mental özellikler alt boyutunun evlilik uyumu üzerinde olumsuz etkisi olduğu görülmektedir. $\mathrm{Bu}$ parametreler değerlendirildiğinde ruhsal durumla değişkenlerin ilişkili olduğu görülmektedir. Ayrıca gelir, eğitim, yaş ve sigara kullanma gibi değişkenlerin evlilik uyumu üzerinde olumsuz etkisinin olduğu görülmektedir. Literatür incelendiğinde bir çalışmada yaş, eğitim durumu, aylık gelir ile evlilik uyumu arasında anlamlı bir ilişki bulmuşlardır. Yaş ilerledikçe evlilik uyumunun azaldığını, eğitim düzeyi ve gelir arttıkça evlilik uyumunun arttığını saptamışlardır (Erbil ve Hazer, 2018). İyi bir gelir algısına sahip olmanın yaşam kalitesini arttıracağından evlilik uyumunu da arttıracağı düşünülmüştür. Yaşın ilerlemesi ile çiftlerin 
evliliğin ilk zamanlarındaki heyecanın azalması, evlilik ve aile yaşamlarındaki sorumluluğun artması ve birbiri ile daha az zaman geçirme gibi faktörlerin evlilik uyumu üzerinde olumsuz etkisi olabileceği düşünülmüştür. Sigara kullananların kullanmayanlara göre premenstrüel dönemde ağr1, konsantrasyon bozukluğu, sivı tutulumu, davranış değişimi, negatif duyguları daha çok yaşadığı belirlenmiştir (Sakai ve ark., 2011). Premenstrüel dönemde yaşanan bu değişimlerin eşler arası iletişimi olumsuz etkileyeceği ve dolayısıyla evlilik uyumu üzerine de olumsuz etkileri olabileceği düşünülmüştür. Çalışma bulguları bu düşünceyi destekler niteliktedir.

\section{Sonuç ve Öneriler}

Araştırma sonuçlarına göre premenstrüel sendromun evlilik uyumunu olumsuz etkilediği görülmüştür. Sağlı profesyonelleri tarafindan kadınlara premenstrüel sendromun belirtilerinin önemi, doğal bir süreçten kaynaklanmadığı, bu belirtilerin ciddi sorunlara neden olabileceği anlatılmalı, bu semptomlarla baş etme metotları öğretilmeli ve kadınlar yardım alma konusunda cesaretlendirilmelidir. Ayrıca kadınların ve eşlerinin birlikte değerlendirildiği tanımlayıcı ve sorunun çözümüne yönelik müdahale türü çalışmaların yapılması önerilebilir.

Araştırmanın Etik Yönü/ Ethics Committee Approval: Araştırma öncesi Necmettin Erbakan Üniversitesi Meram Tıp Fakültesi İlaç ve Tıbbi Cihaz Dışı Araştırmalar Etik Kurul Başkanlığı'ndan 2018/1515 karar sayılı etik kurul onayı alınmıştır. İl sağlık müdürlüğünden araştırmanın Muhtar Fazlı İrge Aile Sağlığı Merkezi' nde yürütülebilmesi için izin alınmıştır. Anket formları doldurulmadan önce kadınlara araştırmanın amacı hakkında bilgi verilip sözel olarak onamları alınmıştır.Araştırma ve yayın etiğine uyulmuştur

Hakem/Peer-review: Dış hakem değerlendirmesi.

Yazar Katkısı/Author Contributions: Fikir/kavram: EB/EE; Tasarım: EB/EE; Danışmanlık: EE; Veri toplama ve Veri İşleme: EB; Analiz ve Yorum: EB/EE; Kaynak Tarama: EB; Makalenin Yazımı: EB/EE; Eleştirel İnceleme:EE

Çıkar çatışması/Conflict of interest: Araştırmada herhangi bir çıkar çatışması bulunmamaktadır.

Finansal Destek/Financial Disclosure: Herhangi bir maddi destek alınmamıştır.

\section{Çalışma Literatüre Ne Kattı?}

- Premenstrüel sendrom semptomları olan evli kadınlara yaklaşım konusunda sağlık profesyonellerine öneriler sunulmuştur.

- Gelecekte yapılacak çalışmalara kaynak olması ve katkı sağlaması açısından önemlidir.

\section{Kaynaklar}

Acikgöz A, Dayi A, Binbay T (2017). Prevalence of premenstrual syndrome and its relationship to depressive symptoms in first-year university students. Saudi Medical Journal, 38(11),1125-1131.

Adıgüzel H, Taşkın Oryal E, Danacı EA (2007). Manisa ilinde premenstrüel sendrom belirti örüntüsü ve belirti yaygınlığının araştırılması. Türk Psikiyatri Dergisi, 18(3), 215-222.

Çoban A, Nehir S, Demirci H, Özbaşaran F, İnceboz Ü (2008). Klimakterik dönemdeki evli kadınların eş uyumları ve menopoza ilişkin tutumlarının menopozal yakınmalar üzerine etkisi. Firat Üniversitesi Sağlık Bilimleri Dergisi, 22(6), 343-349.

Daşıkan Z, Saruhan A (2014). Çalışan hemşirelerde menstrüel yakınmaların incelenmesi. Sürekli Tıp Eğitim Dergisi (STED), 23 (1),1-7.

Dereboy Ç, Dereboy Fİ, Yiğitol F, Çoşkun A (1994). Premenstruel değerlendirme formunun psikometrik verileri: Küme Analitik Bir Çalışma. Türk Psikiyatri Dergisi, 5(2), 83-90.

Eğicioğlu H, Coşar E, Kundak Z, Pektaş M, Köken G (2015). Premenstrüel sendromun yaşam kalitesine olan etkileri sosyodemografik özelliklerle ilişkili mi? Jinekoloji- Obstetrik ve Neonatoloji Tıp Dergisi, 12(1), 10-17.

Erbil Demir D, Hazer O (2018). Çalışan bireylerin evlilik uyumlarının İncelenmesi. International Journal of Eurasian Education anf Culture, 5,99-116.

Erbil N, Bölükbaş N, Tolan S, Uysal F (2011). Evli Kadınlarda premenstrual sendrom görülme durumu ve etkileyen faktörlerin belirlenmesi. Uluslararası İnsan Bilimleri Dergisi, 8(1),427-438.

Erbil N, Karaca A, Kırış T (2010). Investigation of premenstrual syndrome and constributing factors among university stıdents. Turkısh Journal of Medical Sciences,40(4),565-573.

George D, Mallery M (2010). SPSS for Windows Step by Step: A Simple Guide and Reference, 17.0 update (10a ed.). Boston: Pearson.

Heydaria N, Abootalebib M, Jamalimoghadamc N, Kasraeiand M, Emamghoreishie M, Akbarzadehf M (2018). Evaluation of aromatherapy with essentialoils of rosa damascena for the management of premenstrual syndrom. International Federation of Gynecology and Obstetrics,142,156-161.

Hussein Shehadeh J, Hamdan-Mansour AM (2018). Prevalence and association of premenstrual syndrome 
and premenstrual dysphoric disorder with academic performance among female university students.Perspect Psychiatr Care, 54, 176-184.

Kaya D, Gölbaşı Z (2016). Hemşirelik / Ebelik öğrencilerinde premenstrual sendrom yaygınlığ 1 ve premenstrual sendromun sigara içme davranışı ile ilişkisi. TAF (Turkish Armed Forces) Preventive Medicine Bulletin, 15 (4), 305-311.

Kebapcılar AG, Taner CE, Başoğlu Ö, Okan G (2012). İzmir Ege Doğumevi ve Kadın Hastalıkları Eğitim ve Araştırma Hastanesi hastalarındaki premenstrüel sendrom prevelansı ve etkileyen faktörler. Firat Üniversitesi Sağlık Bilimleri Tıp Dergisi, 26(3), 111114.

Kıvrak AO, Taşğın Ö (2010). Beden eğitimi ve spor yüksekokulunda öğrenim gören kız öğrencilerin premenstrüel sendrom düzeyleri. Dicle Üniversitesi Ziya Gökalp Eğitim Fakültesi Dergisi, 15, 110-119.

Kublay D, Oktan V (2015). Evlilik Uyumu: Değer tercihleri ve öznel mutluluk açısından incelenmesi. Türk Psikolojik Danışma ve Rehberlik Dergisi,5(44), 25-35.

Lemeshow S, Hosmer DW, Klar J, Lwanga SK (2000). Sağlık araştırmalarında örneklem büyüklüğünün yeterliliği. Çeviren: S. Oğuz Kayaalp. P.143.

Morowatisharifabad MA, Karimiankakolaki Z, Bokaie M, Fallahzadeh H, Gerayllo S (2014). The effects of training married men about premenstrual syndrome by pamphlets and short messages on marital satisfaction. Health Education Research, 29(6), 1005 1014.

Nicolaua ZFM, Bezerraa AG, Polesela D N, Andersena M L, Bittencourta L, Tufika S, Hachula H (2018). Premenstrual syndrome and sleep disturbances: Results from the Sao Paulo Epidemiologic Sleep Study. Psychiatry Research, 264, 427-431.

Özeren A, Atilla D, Helvacı M (2013). Hastane çalışanlarında premenstrüel sendrom ve depresyon ile ilişkisi. Tepecik Eğitim Hastanesi Dergisi, 23 (1), 25 33.

Özkan S, Koç G (2020). Kadınlarda premenstrual sendrom yaşanmasını etkileyen sosyal ve kültürel faktörler. HUHEMFAD (Hacettepe Üniversitesi Hemşirelik Fakültesi Dergisi),7(2), 180-185.

Öztürk Can H, Baykal Akmeşe Z. ve Durmuş B (2015). Sınıf öğretmenlerinde premenstrüel sendrom görülme durumu ile sürekli öfke ve öfke tarzları arasındaki ilişki. NWSA (New World Sciences Academy)- Life Sciences, 4B0005, 10(1), 1-13.

Pınar A, Öncel S (2011). 15-49 yaş grubu kadınlarda premenstrual sendrom görülme sıklığ (Antalya/Türkiye). Türkiye Klinikleri Journal Gynecoly Obstetric, 21(4), 227-237

Saka S, Okuyucu T (2020). Genç kadınlarda premenstrual sendromun yorgunluk ve uyku kalitesi üzerine etkisi. Haliç Üniversitesi Sağlık Bilimleri Dergisi,3(1), 33-39.
Sakai H, Kawamura C, Cardenas X, Ohashi K (2011). Premenstrual and menstrual symptomatology in young adult Japanese females who smoke tobacco. Journal of Obstetric and Gynaecology Research, 37(4), 325-30.

Sakarya E, Dilmaç B (2020). Evli bireylerin evlilik uyum, yaşam memnuniyeti ve yaşam bağlılıkları arasındaki yordayıcı ilişkilerin incelenmesi. Necmettin Erbakan Üniversitesi Ereğli Eğitim Fakültesi Dergisi, 2(1), 111.

Tanrıverdi G, Selçuk E, Okanlı A (2010). Üniversite Öğrencilerinde Premenstrual Sendrom Prevalans1. Anadolu Hemşirelik ve Sağlık Bilimleri Dergisi,13(1), 52-57.

Taşç1, KD (2006). Hemşirelik öğrencilerinin premenstrual semptomlarının değerlendirilmesi. TSK (Türk Silahlı Kuvvetleri) Koruyucu Hekimlik Bülteni,5(6), 434-443.

Tok D, Avc1 P (2015). Premenstrüel Sendrom ve Premenstrüel Disforik Bozukluk. Obstetrik ve Jinokoloji. Editörler: Demir SC, Güleç Küçükgöz Ü. Akademisyen Tip Kitabevi, 7.Baskı, Ankara, Türkiye, 381-386.

Tutarel - Kışlak Ş, Göztepe I (2012). Duygu dışavurumu, empati, depresyon ve evlilik uyumu arasındaki ilişkiler. Ankyra: Ankara Üniversitesi Sosyal Bilimler Enstitüsü Dergisi, 3(2), 27-46.

Tutarel-Kışlak, Ş (1999). Evlilikte uyum ölçeğinin (EUÖ) güvenirlik ve geçerlik çalışması. 3P Psikoloji, Psikiyatri ve Psikoloji Dergisi, 7(1), 50-57.

Türkseven A, Söylemez İ, Dursun P (2020). Cinsel işlev bozuklukları ile evlilik uyumu arasındaki ilişkisi. Kriz Dergisi, 28(1), 9-20.

Yücel U, Bilge A, Oran N, Ersoy MA, Gençdoğan B, Özveren Ö (2009). Adolesanlarda premenstruel sendrom yaygınlığ 1 ve depresyon riski arasındaki ilişki. Anadolu Psikiyatri Dergisi, 10, 55-61. 